\title{
Identifikasi Penguasaan Konsep Fisika Siswa SMA Kelas XI dan XII pada Materi Suhu dan Kalor
}

\author{
Umi Azizah ${ }^{1}$, Parno $^{1}$, Edi Supriana ${ }^{1}$ \\ ${ }^{1}$ Pendidikan Fisika-Universitas Negeri Malang
}

\begin{tabular}{l}
\hline \hline INFO ARTIKEL \\
\hline Riwayat Artikel: \\
Diterima: 08-03-2019 \\
Disetujui: 19-04-2019 \\
\hline
\end{tabular}

\section{Kata kunci:}

mastery of concepts; heat and temperature; multiple choice reasons; penguasaan konsep; suhu dan kalor; pilihan ganda beralasan

\author{
Alamat Korespondensi: \\ Umi Azizah \\ Pendidikan Fisika \\ Universitas Negeri Malang \\ Jalan Semarang 5 Malang \\ E-mail: parno.fmipa@um.ac.id
}

\begin{abstract}
This study aims to identify mastery of high school students physic concepts in different classes on heat and temperature. This study is classified as quantitative descriptive with research subjects in class eleven and twelve totaling 62 students. Class eleven students just received the study and class twelve received study a year ago. Instrument used Mastery Test Concept of Heat and Temperature with reliability of 0.884 . Student answers are categorized into 3 criteria, high, medium, and low. The results of the study revealed that overall students of class eleven are in high criteria and class twelve is in the low criteria.
\end{abstract}

ABSTRAK

\begin{abstract}
Abstrak: Penelitian ini bertujuan untuk mengidentifikasi penguasaan konsep fisika siswa SMA dengan kelas yang berbeda pada materi suhu dan kalor. Penelitian ini tergolong sebagai deskriptif kuantitatif dengan subjek penelitian kelas XI dan XII berjumlah 62 siswa. Siswa kelas XI baru menerima materi dan kelas XII menerima materi setahun yang lalu. Instrumen yang digunakan berupa Tes Penguasaan Konsep Suhu dan Kalor jenis pilihan ganda beralasan dengan reliabilitas 0,884. Jawaban siswa dikategorikan menjadi tiga kriteria, yaitu penguasaan konsep tinggi, sedang, dan rendah. Hasil penelitian mengungkapkan bahwa secara keseluruhan siswa kelas XI berada pada kriteria tinggi dan kelas XII berada pada kriteria rendah.
\end{abstract}

Suhu dan kalor merupakan salah satu topik yang dekat dengan kehidupan sehari-hari, tetapi fenomena-fenomenanya sulit untuk dijelaskan secara ilmiah oleh siswa (Thomaz, Malaquias, Valente, \& Antunes, 1995). Banyak siswa menganggap sulit materi suhu dan kalor. Materi suhu dan kalor memiliki konsep yang sulit sehingga siswa merasa kebingungan dalam memahami materi suhu dan kalor (Yaşar \& Sözbilir, 2012). Sebagian besar siswa mengalami kesulitan memahami materi konsep suhu dan kalor, meliputi konsep suhu, konsep kalor, perpindahan kalor dan titik didih air (Alwan, 2011). Di lain sisi, siswa harus menguasai konsep-konsep tersebut untuk menjawab permasalahan terkait suhu dan kalor dalam kehidupan sehari-hari.

Beberapa penelitian yang meliputi dari 5000 siswa fisika di 30 institusi menunjukkan bahwa penguasaan konsep siswa dalam pembelajaran fisika tidak memuaskan (Maloney, O’Kuma, Hieggelke, \& Van Heuvelen, 2001). Penelitian sebelumnya juga mengungkapkan bahwa ketika siswa diberikan soal cerita atau tanpa persamaan matematis, siswa cenderung menjawab permasalahan dengan membangun penguasaan konsep fisika melalui persamaan matematis daripada melalui jawaban uraian yang berisi konsep secara verbal (Hung \& Jonassen, 2006; Jonassen, 2003; Van Heuvelen, 1991). Oleh karena itu, penguasaan konsep fisika menjadi sangat penting karena termasuk indikator bahwa siswa telah memahami sepenuhnya apa yang telah diajarkan, bukan sekedar menghafal.

Berdasarkan silabus pada indikator kompetensi dasar materi suhu dan kalor yang diajarkan di kelas XI dalam penggalan kurang berkaitan dengan topik-topik yang lain. Materi yang mengaitkan indikator kalor hanya menjadi dasar untuk mempelajari termodinamika, yakni setelah materi suhu dan kalor berlangsung. Hal ini berarti siswa kelas XII tidak lagi mengaitkan konsep/prinsip suhu dan kalor sehingga siswa kelas XII akan mengalami faktor tidak terbentuknya struktur pengetahuan (network of knowledge) sehingga siswa cenderung lupa terhadap materi suhu dan kalor yang telah diajarkan pada kelas XI (Lestari \& Linuwih, 2014). Oleh karena itu, perlu untuk mengidentifikasi penguasaan konsep fisika materi suhu dan kalor di dua kelas, yaitu kelas XI dan XII karena pembelajaran suhu kalor saat ini dipelajari di kelas XI.

\section{METODE}

Jenis penelitian ini menggunakan metode deskriptif kuantitatif. Subjek penelitian yaitu siswa SMA kelas XI dan XII berjumlah 62 siswa dengan kelas XI berjumlah 31 siswa baru menerima materi suhu dan kalor dan kelas XII berjumlah 31 siswa telah menerima materi suhu dan kalor setahun yang lalu. Instrumen yang digunakan adalah Tes Penguasaan Konsep Suhu 
dan Kalor sebanyak 10 soal pilihan ganda beralasan dengan reliabilitas 0,884 . Penelitian ini hanya menggunakan indikator penguasaan konsep taksonomi Bloom $\mathrm{C} 2-\mathrm{C} 4$ sebagaimana terdapat pada tabel 1. Hasil tes penguasaan konsep pilihan ganda beralasan dinilai dengan kategori penilaian pada tabel 2 merujuk pada (Zainab \& Wilujeng, 2016).

\section{Tabel 1. Indikator Taksonomi Bloom}

\begin{tabular}{cll}
\hline No. & \multicolumn{1}{c}{ Indikator } & \multicolumn{1}{c}{ Soal No. } \\
\hline 1 & Menjelaskan pemuaian zat yang terjadi pada suatu benda (C2) & 2,3 \\
2 & Menerapkan konsep pemuaian dalam kehidupan sehari-hari (C3) & 1 \\
3 & Menerapkan kalor jenis bahan terhadap perubahan suhu (C3) & 4 \\
4 & Menerapkan perpindahan kalor pada kehidupan sehari-hari (C3) & 9,10 \\
5 & Menerapkan asas Black dalam kehidupan sehari-hari (C3) & 7,8 \\
6 & Menganalisis pengaruh kalor terhadap suhu, massa, dan kalor jenis benda (C4) & 5,6 \\
\hline
\end{tabular}

Tabel 2. Kategori Penilaian Soal Pilihan Ganda Beralasan

\begin{tabular}{cl}
\hline Kategori & \multicolumn{1}{c}{ Penilaian } \\
\hline 0 & Jika tidak memilih jawaban dan tidak memberi alasan. \\
1 & Jika memilih jawaban salah dan memberi alasan salah. \\
2 & Jika memilih jawaban benar dan memberi alasan salah. \\
3 & Jika memilih jawaban salah dan memberi alasan benar \\
4 & Jika memilih jawaban benar dan memberi alasan benar. \\
\hline
\end{tabular}

Untuk menghitung persentase skor penguasaan konsep siswa materi suhu dan kalor menggunakan rumus sebagai berikut (Sudijono, 2008).

$$
N=\frac{\sum \text { skor perolehan }}{\sum \text { skor maksimal }} \times 100 \%
$$

Kriteria yang didapatkan dari hasil persentase skor penguasaan konsep siswa materi suhu dan kalor dikualifikasikan berdasarkan tabel 3 (Arikunto, 2004).

Tabel 3. Kualifikasi Hasil Tes Berdasarkan Indikator Penguasaan Konsep

\begin{tabular}{cl}
\hline Rentang Skor $(\%)$ & Kriteria \\
\hline $66,68 \leq \mathrm{Z} \leq 100$ & Tinggi \\
$33,34 \leq \mathrm{Z} \leq 66,67$ & Sedang \\
$0 \leq \mathrm{Z} \leq 33,34$ & Rendah \\
\hline
\end{tabular}

\section{HASIL}

Kriteria Penguasaan Konsep Siswa Berdasarkan Indikator C2_C4

Penguasaan konsep siswa kelas XI dan XII materi suhu dan kalor diperoleh dari hasil tes pilihan ganda beralasan. Hasil yang didapat untuk tingkat penguasaan konsep kelas XI dan XII dapat dilihat pada tabel 4.

Tabel 4. Tingkat Penguasaan Konsep Siswa kelas XI dan XII

\begin{tabular}{lllllllllllllll}
\hline \multirow{2}{*}{ Kriteria } & \multicolumn{10}{c}{ Jumlah Siswa (\%) } & \multicolumn{1}{c}{ C3 } & \multicolumn{1}{c}{ C4 } & \multicolumn{2}{c}{ Rata-rata } \\
\cline { 2 - 15 } & \multicolumn{1}{c}{ C2 } & \multicolumn{1}{c}{ XII } & \multicolumn{1}{c}{ XI } & XII & XI & XII & XI & XII \\
\hline Tinggi & 24 & $77 \%$ & 7 & $24 \%$ & 25 & $80 \%$ & 9 & $30 \%$ & 27 & $87 \%$ & 5 & $15 \%$ & $82 \%$ & $23 \%$ \\
Sedang & 2 & $6 \%$ & 5 & $15 \%$ & 2 & $5 \%$ & 6 & $19 \%$ & 1 & $3 \%$ & 6 & $19 \%$ & $5 \%$ & $18 \%$ \\
Rendah & 5 & $16 \%$ & 19 & $61 \%$ & 5 & $15 \%$ & 16 & $51 \%$ & 3 & $10 \%$ & 21 & $66 \%$ & $14 \%$ & $60 \%$ \\
\hline
\end{tabular}

Tabel 4 menunjukkan bahwa dari 31 siswa kelas XI rata-rata siswa berada pada penguasaan konsep kriteria tinggi pada indikator $\mathrm{C} 2-\mathrm{C} 4$ persentase siswa pada indikator C2 sebanyak 24 siswa atau 77\%, indikator C3 25 siswa atau $80 \%$, dan indikator C4 sebanyak 27 siswa atau 87\%. Namun, pada kelas XII persentase terbesar siswa berada pada penguasaan konsep kriteria rendah dapat dilihat dari indikator C2-C4. Indikator C2 sebanyak 19 siswa atau 61\%, indikator C3 sebanyak 16 siswa atau 51\%, dan indikator C4 sebanyak 21 siswa atau 66\%. Hal ini menunjukkan bahwa kebanyakan siswa kelas XI berada pada penguasaan konsep kriteria tinggi dan kelas XII berada pada penguasaan konsep kriteria rendah. 


\section{Kriteria Penguasaan Konsep Siswa Berdasarkan Indikator Tiap Sub Materi}

Persentase jumlah siswa berdasarkan indikator setiap sub materi untuk kelas XI dan XII dibagi menjadi tiga kriteria yang ditampilkan pada tabel 5 .

Tabel 5. Hasil Tes Pilihan Ganda Beralasan pada Materi Suhu dan Kalor

\begin{tabular}{|c|c|c|c|c|c|c|c|}
\hline \multirow{3}{*}{ No. } & \multirow{3}{*}{ Indikator } & \multicolumn{6}{|c|}{ Jumlah Siswa (\%) } \\
\hline & & \multicolumn{2}{|c|}{ Tinggi } & \multicolumn{2}{|c|}{ Sedang } & \multicolumn{2}{|c|}{ Rendah } \\
\hline & & $\mathbf{X I}$ & XII & XI & XII & XI & XII \\
\hline 1 & Menjelaskan pemuaian zat yang terjadi pada suatu benda $(\mathrm{C} 2)$ & $77 \%$ & $21 \%$ & $6 \%$ & $15 \%$ & $16 \%$ & $61 \%$ \\
\hline 2 & Menerapkan konsep pemuaian dalam kehidupan sehari-hari (C3) & $61 \%$ & $29 \%$ & $16 \%$ & $16 \%$ & $23 \%$ & $55 \%$ \\
\hline 3 & Menerapkan kalor jenis bahan terhadap perubahan suhu (C3) & $94 \%$ & $23 \%$ & $3 \%$ & $13 \%$ & $3 \%$ & $65 \%$ \\
\hline 4 & Menerapkan perpindahan kalor pada kehidupan sehari-hari (C3) & $90 \%$ & $42 \%$ & $2 \%$ & $23 \%$ & $2 \%$ & $35 \%$ \\
\hline 5 & Menerapkan asas Black dalam kehidupan sehari-hari (C3) & $73 \%$ & $23 \%$ & $6 \%$ & $18 \%$ & $21 \%$ & $60 \%$ \\
\hline 6 & Menganalisis pengaruh kalor terhadap suhu, massa, dan kalor jenis benda (C4) & $87 \%$ & $15 \%$ & $3 \%$ & $19 \%$ & $10 \%$ & $66 \%$ \\
\hline \multicolumn{2}{|r|}{ Rata-rata } & $80 \%$ & $26 \%$ & $6 \%$ & $17 \%$ & $13 \%$ & $57 \%$ \\
\hline
\end{tabular}

Tabel 5 menunjukkan bahwa siswa kelas XI dapat menyelesaikan soal materi suhu kalor pada indikator ke-3, yakni menerapkan kalor jenis bahan terhadap perubahan suhu, dengan kriteria penguasaan konsep tinggi sebesar 94\% siswa. Siswa dapat menerapkan perbedaan nilai kalor jenis bahan terhadap perubahan suhu dengan baik. Namun, dapat dilihat bahwa siswa kelas XI dan XII sedikit yang berada pada kriteria sedang hal ini dikarenakan siswa pada menjawab soal pilihan ganda beralasan hanya dengan menjawab pilihan ganda tanpa mengungkapkan alasan atau memberi alasan salah (skor 2). Pada penguasaan konsep kategori rendah persentase terbesar terletak pada kelas XII indikator menganalisis pengaruh kalor terhadap suhu, massa, dan kalor jenis bahan. Siswa pada indikator ini sebanyak 66\% siswa tidak memberi jawaban dan tidak memberi alasan (skor 1) atau memberi jawab dan alasan salah (skor 2).

\section{PEMBAHASAN}

Kriteria Penguasaan Konsep Siswa Berdasarkan Indikator C2-C4

Penguasaan siswa berbeda antara kelas XI dan XII. Keseluruhan indikator C2-C4 menunjukkan bahwa siswa kelas XI menuju pada kriteria tinggi dan siswa kelas XI masih berada pada penguasaan konsep kriteria rendah. Berdasarkan penelitian sebelumnya tentang suhu kalor yang dilaksanakan di dua tingkat kelas, yaitu kelas X dan XII mengungkapkan bahwa siswa kelas X masih mengalami konsepsi yang disebabkan oleh beberapa faktor, yaitu pemahaman kurang mendalam, apresiasi konseptual, intuisi dalam kehidupan sehari-hari, dan menganggap pengetahuan adalah struktur teoritis, sedangkan pada kelas XII terjadi karena faktor tidak terbentuknya struktur pengetahuan (network of knowledge) sehingga siswa cenderung sudah lupa terhadap materi yang sudah diajarkan di kelas X (Lestari \& Linuwih, 2014).

Perbedaan kriteria akibat dari perbedaan waktu siswa yang telah mempelajari materi suhu dan kalor, guru yang berbeda dan model pembelajaran yang berbeda pula. Siswa kelas XI yang baru menerima materi suhu dan kalor, sedangkan kelas XII telah menerima materi suhu dan kalor setahun yang lalu. Meskipun demikian, $42 \%$ siswa kelas XII dapat menerapkan indikator perpindahan kalor pada kehidupan sehari-hari. Penelitian sebelumnya juga mengungkapkan bahwa kelemahan siswa pada saat menjawab soal materi suhu dan kalor adalah siswa mengalami kesalahan dalam memahami konsep, kesalahan dalam menghitung, dan kesalahan saat siswa menerapkan materi suhu dan kalor pada kehidupan sehari-hari (Silaban, 2015). Siswa sulit memecahkan soal penguasaan konsep tersebut meskipun telah dipelajari sejak di bangku SMP (Wahidah, Kusairi, \& Zulaikah, 2017).

\section{Persentase Penguasaan Konsep Siswa Berdasarkan Indikator Tiap Sub Materi Penguasaan Konsep Kriteria Tinggi}

Penguasaan konsep kriteria tinggi terlihat pada soal nomor 4 dengan indikator menerapkan kalor jenis bahan terhadap perubahan suhu. Siswa kelas XI $94 \%$ dan kelas XII 23\%. Terdapat perbedaan yang signifikan antara persentase penguasaan konsep siswa kelas XI dan XII. Penelitian sebelumnya mengungkapkan bahwa jika siswa mengalami kesulitan saat diberi permasalahan suhu dan kalor berarti siswa belum menguasai konsep dengan benar (Docktor, Strand, Mestre, \& Ross, 2015). Butir soal penguasaan konsep nomor 4 ditampilkan pada gambar 1 . 
4. Jika kalian memanggang kentang yang dibungkus kertas alumunium, setelah kentang matang

kertas alumunium dilepaskan. Manakah yang akan lebih cepat dingin, kentang atau kertas

kertas alumuniun

a. Kentang

b. Sama-sama cepat mendingin

$\checkmark$ X. Alumunium

d. Tidak ada jawaban

alasan:

Kertas alumuniom akan lebin cepat ringin dibandinglean kentang

$\checkmark$ karena alumunium mèruliki kalor jenis yaug tinggi. Sehingga

alomunium mampu menyerap Kalor lebih banyah dan juga mampy

melepas kabr lebih bayyah dibanding kentang.

(a)

4. Jika kalian memanggang kentang yang dibungkus kertas alumunium, setelah kentang matang

kertas alumunium dilepaskan. Manakah yang akan lebih cepat dingin, kentang atau kertas

3 alumunium?

a. Kentang

b. Sama-sama cepat mendingin

c. Alumunium

$X$ Tidak ada jawaban

alasan:

$\checkmark$ Karena kalor jenis alumunium lebih tinggi dari pacla kentang

(b)

Gambar 1. Butir Soal Nomor 4 Beserta Jawaban Siswa (a) Kelas XI dan (b) XII

Pada soal nomor 4 dapat (gambar 1 a) menunjukkan jawaban siswa kelas XI yang mendapat skor 4 dengan menjawab pilihan ganda benar dan alasan benar. Siswa telah dapat menerapkan kalor jenis bahan terhadap perubahan suhu. Sementara itu, (gambar 1 b) menunjukkan jawaban siswa kelas XII yang mendapat skor 3 dengan jawaban pilihan ganda salah, namun dapat memberikan alasan benar. Siswa yang dapat menjawab dengan skor 4 dan 3 termasuk ke dalam penguasaan konsep kriteria tinggi.

\section{Penguasaan Konsep Kriteria Sedang}

Soal dengan penguasaan konsep kriteria sedang salah satunya butir soal nomor 1 pada indikator menerapkan pemuaian dalam kehidupan sehari-hari. Kelas XI 16\% siswa dan kelas XII 16\% siswa. Butir soal nomor 1 dapat dilihat pada gambar 1. 1. Sebuah tong besi (koefisien muai panjang besi adalah $\left(12 \times 10^{-6} /{ }^{\circ} \mathrm{C}\right)$ bervolume 70 liter

diisi minyak sampai penuh (koefisien muai volum $20^{\circ} \mathrm{C}$. pada siang hari suhu naik menjadi dihalaman rumah pada saat pagi hari dengan suhu $20 \mathrm{C}$. pada siangah sebanyak...

a. 0,125 liter

b. 1,25 liter

c. 1,28 liter

d. 5 liter

alasan: 
C. Sebuah tong besi (koefisien muai panjang besi adalah $\left(12 \times 10^{-6} /{ }^{\circ} \mathrm{C}\right)$ bervolume 70 lite diisi minyak sampai penuh (koefisien muai volum $950 \times 10^{-6} /{ }^{\circ} \mathrm{C}$ ) dan diletakkan

dihalaman rumah pada saat pagi hari dengan suhu $20^{\circ} \mathrm{C}$. pada siang hari suhu naik

$40^{\circ} \mathrm{C}$, akibatnya terjadi pemuaian minyak yang sebagiannya tumpah a. 0,125 liter b. 1,25 liter

$\checkmark \times 1,28$ liter

d. 5 liter

alasan:

Diketahui : $\alpha_{\text {ber }}: 12 \times 10^{-6} \mathrm{l}^{\mathrm{C}} \mathrm{c}$

$v: 70$ liter

$\gamma_{\text {minyak }}: 950 \times 10^{-6} /{ }^{\circ} \mathrm{C}$

$T_{1}: 20^{\circ} \mathrm{C}$

$T_{2}: 40^{\circ} \mathrm{C}$

ditanya minyak yang tertutup?

jawab?

(b)

Gambar 2. Butir Soal Nomor 1 Beserta Jawaban Siswa (a) Kelas XI dan (b) XII

Siswa pada indikator ini tidak dapat menjawab alasan dengan benar. Siswa belum bisa menerapkan konsep pemuaian. Siswa belum bisa membedakan bahwa koefisien muai panjang dan muai volume adalah beda. Kebanyakan dari mereka belum mengerti bahwa koefisien muai volume adalah tiga kali dari koefisien muai panjang. Sebagian siswa juga hanya menjawab pilihan ganda tanpa menuliskan alasan. Dalam kriteria ini siswa akan mendapat skor 2. Penelitian sebelumnya juga menyatakan bahwa pada materi suhu dan kalor indikator menerapkan berada dalam kriteria penguasaan konsep sedang (Simanjuntak, 2014).

\section{Penguasaan Konsep Kriteria Rendah}

Soal dengan penguasaan konsep kriteria rendah dengan yaitu pada butir soal nomor 5 dan 6 pada indikator Menganalisis pengaruh kalor terhadap suhu, massa, dan kalor jenis benda. Kelas XI sebanyak 10\% siswa dan kelas XII 66\% siswa. Salah satu butir soal dengan siswa berada kriteria rendah yang ditampilkan adalah butir soal nomor 6 , butir tersebut dapat dilihat pada gambar 3. Pada kriteria ini, kebanyakan siswa memberi jawaban pilihan ganda dan memberikan alasan salah (skor 1), dan siswa tidak menjawab pilihan ganda juga tidak memberikan alasannya (skor 0). Akan tetapi, masih banyak juga siswa yang berada pada penguasaan konsep kriteria sedang dan tinggi pada sub materi lainnya. Butir soal nomor 5 ditampilkan pada gambar 3 .

6. Dari sebuah percobaan diperoleh data sebagai berikut

\begin{tabular}{|c|c|c|c|c|}
\hline $\begin{array}{l}\mathrm{m} \\
(\mathrm{kg})\end{array}$ & $\mathrm{c}\left(\mathrm{J} / \mathrm{kg}^{\circ} \mathrm{C}\right)$ & $\begin{array}{l}\text { Suhu } \\
\text { awal } \\
\left({ }^{\circ} \mathrm{C}\right)\end{array}$ & $\begin{array}{l}\text { Suhu } \\
\text { akhir } \\
\left({ }^{\circ} \mathrm{C}\right)\end{array}$ & $Q(J)$ \\
\hline 0,05 & \multirow{4}{*}{4200} & 20 & 41 & 4.410 \\
\hline 0,1 & & 20 & 39 & 7.980 \\
\hline 0,015 & & 20 & 36 & 10.080 \\
\hline 0,2 & & 20 & 33 & 10.920 \\
\hline
\end{tabular}

Berdasarkan data hasil percobaan diatas, didapat rumusan bahwa..
a. $\mathrm{Q}=\mathrm{m} \mathrm{c} / \Delta \mathrm{T}$
b. $\mathrm{m}=\mathrm{Q} / \mathrm{c} \Delta \mathrm{T}$
$\times$ c. $\mathrm{Q}=\mathrm{m} / \mathrm{c} \Delta \mathrm{T}$
d. $Q=m / c$

Alasan:

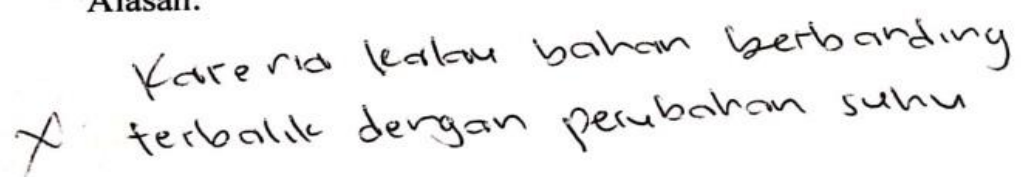

(a) 


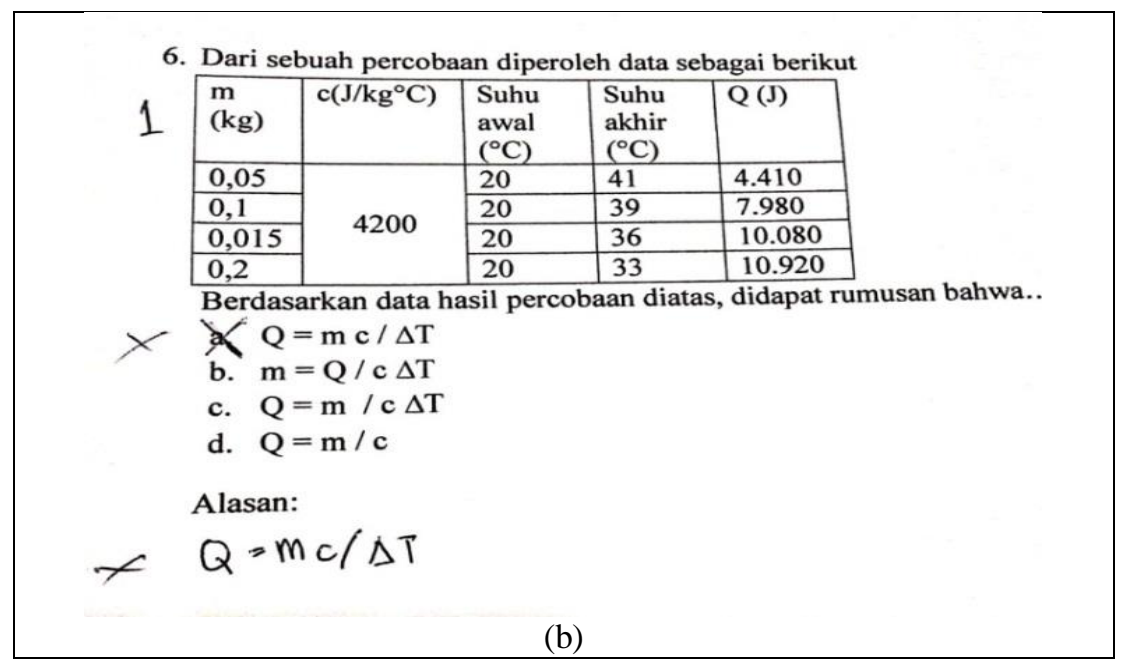

\section{Gambar 3. Butir Soal Nomor 1 Beserta Jawaban Siswa (a) Kelas XI dan (b) XII}

Pada gambar 3 menunjukkan jawaban siswa berada pada kriteria rendah dengan skor 1 karena siswa menjawab pilihan ganda dan memberikan alasan salah. Hal ini sesuai dengan penelitian sebelumnya yang menyatakan bahwa konsep-konsep yang terkait suhu dan kalor, meliputi suhu, kalor, perpindahan kalor, dan pengaruh kalor terhadap benda, meliputi pemuaian, perubahan suhu, dan perubahan wujud adalah konsep yang sulit dipahami oleh siswa (Wahidah, et al., 2017).

\section{SIMPULAN}

Secara keseluruhan, penguasaan konsep siswa materi suhu dan kalor terdapat perbedaan antara kelas XI dan XII. Kebanyakan siswa kelas XI berada pada kriteria penguasaan konsep tinggi dan kelas XII berada pada penguasaan konsep kriteria rendah. Kriteria penguasaan konsep dibagi menjadi tiga, yaitu tinggi, sedang, dan rendah. Kriteria tinggi kelas XII 25 $(82 \%)$ siswa, kriteria sedang sebanyak 2 (5\%) siswa, dan kriteria rendah sebanyak 4 (14\%) siswa. Sementara itu, kelas XII pada kriteria tinggi 7 (23\%) siswa, kriteria sedang 5 (18\%) siswa, dan kriteria rendah 18 (60\%) siswa.

Berdasarkan persentase penguasaan konsep terdapat 10 butir soal yang dibagi dalam enam indikator. Penguasaan konsep kriteria tinggi terlihat pada soal nomor 4 dengan indikator menerapkan kalor jenis bahan terhadap perubahan suhu. Kelas XI 94\% siswa dan kelas XII 23\% siswa. Soal dengan penguasaan konsep kriteria sedang salah satunya butir soal nomor 1 pada indikator menerapkan pemuaian dalam kehidupan sehari-hari. Kelas XI 16\% siswa dan kelas XII 16\% siswa. Soal dengan penguasaan konsep kriteria rendah dengan yaitu pada butir soal nomor 5 dan 6 pada indikator menganalisis pengaruh kalor terhadap suhu, massa, dan kalor jenis benda. Kelas XI 10\% siswa dan kelas XII 66\% siswa. Siswa yang masih mengalami kesulitan tentang pengaruh kalor terhadap suhu, massa, dan kalor jenis benda masih perlu untuk mempelajari dan melatih kembali tentang konsep-konsep kalor.

Penelitian lebih lanjut disarankan untuk mengungkapkan atau mengeksplorasikan penyebab siswa mengalami kesulitan dalam menguasai konsep suhu dan kalor. Disarankan juga untuk menerapkan berbagai pendekatan pembelajaran yang dapat meningkatkan penguasaan konsep siswa.

\section{DAFTAR RUJUKAN}

Alwan, A. A. (2011). Misconception of Heat and Temperature among Physics Students. Procedia - Social and Behavioral Sciences, 12, 600-614. https://doi.org/10.1016/j.sbspro.2011.02.074

Arikunto, S. (2004). Evaluasi Program Pendidikan. Bumi Aksara.

Docktor, J. L., Strand, N. E., Mestre, J. P., \& Ross, B. H. (2015). Conceptual Problem Solving in High School Physics. Physical Review Special Topics - Physics Education Research, 11(2). https://doi.org/10.1103/PhysRevSTPER.11.020106

Hung, W., \& Jonassen, D. H. (2006). Conceptual Understanding of Causal Reasoning in Physics. International Journal of Science Education, 28(13), 1601-1621. https://doi.org/10.1080/09500690600560902

Jonassen, D. H. (2003). Designing Research-Based Instruction for Story Problems. Educational Psychology Review, 15(3), 267-296.

Lestari, P. P., \& Linuwih, S. (2014). Analisis Konsepsi dan Perubahan Konseptual Suhu dan Kalor pada Siswa SMA Kelas Unggulan. UPEJ Unnes Physics Education Journal, 3(2). https://doi.org/10.15294/upej.v3i2.3599

Maloney, D. P., O’Kuma, T. L., Hieggelke, C. J., \& Van Heuvelen, A. (2001). Surveying Students' Conceptual Knowledge of Electricity and Magnetism. American Journal of Physics, 69(S1), S12-S23. https://doi.org/10.1119/1.1371296

Silaban, S. S. (2015). Analisis Didaktik Berdasarkan Profil Penguasaan Konsep Siswa pada Materi Suhu dan Kalor. Prosiding Simposium Nasional Inovasi dan Pembelajaran Sains (SNIPS 2015), 4. 
Simanjuntak, M. P. (2014). Efektivitas Model Problem Based Learning terhadap Penguasaan Konsep Mahasiswa pada Konsep Suhu dan Kalor. Jurnal Inpafi, 2(3), 8.

Sudijono, A. (2008). Pengantar Evaluasi Pendidikan. Raja Grafindo Persada.

Thomaz, M. F., Malaquias, I. M., Valente, M. C., \& Antunes, M. J. (1995). An Attempt to Overcome Alternative Conceptions Related to Heat and Temperature. Physics Education, 30(1), 19-26. https://doi.org/10.1088/0031-9120/30/1/004

Van Heuvelen, A. (1991). Learning to Think Like a Physicist: A Review of Research-Based Instructional Strategies. American Journal of Physics, 59(10), 891-897. https://doi.org/10.1119/1.16667

Wahidah S., S. N., Kusairi, S., \& Zulaikah, S. (2017). Diagnosis Miskonsepsi Siswa SMA di Kota Malang pada Konsep Suhu dan Kalor menggunakan Three Tier Test. Jurnal Pendidikan Fisika dan Teknologi, 2(3), 95. https://doi.org/10.29303/jpft.v2i3.295

Yaşar, M. D., \& Sözbilir, M. (2012). Teachers' Views about 2007 Chemistry Curriculum and Problems Encountering During the Implementation: The Case of Erzurum. Journal of Education Faculty, 14(2), 359-392. https://doi.org/10.17556/jef.77206

Zainab, S., \& Wilujeng, D. I. (2016). Pengembangan Instrumen Penilaian Tes Objektif Pilihan Ganda untuk Mengukur Penguasaan Materi Ajar Gerak Lurus dan Keterampilan Proses Sains Siswa SMA. Jurnal Pendidikan Fisika, $5(2), 8$. 